\title{
Role of APP in neuronal function
}

\author{
Hui Zheng \\ From Molecular Neurodegeneration: Basic biology and disease pathways \\ Cannes, France. 10-12 September 2013
}

\section{Background}

Genetic and biochemical studies establish a central role of the amyloid precursor protein (APP) in Alzheimer's disease (AD): Genetic mutations and gene amplification of APP are linked to early onset of familial Alzheimer's disease (FAD); APP processing generates $\beta$-amyloid $(\mathrm{A} \beta)$ peptides, which are the principal components of the amyloid pathology. Therefore, understanding the role of APP in neuronal function and dysfunction will provide crucial insights to $\mathrm{AD}$ pathogenesis.

\section{Results}

We have a long-standing interest in studying the physiological functions of APP in neurons and synapses. Analysis of various loss-of-function mutants of APP and combining with a mixed-culture system allowed us to identify APP as a synaptic adhesion protein. We recently uncovered a potent role of APP in mediating adult neurogenesis in dentate gyrus: Loss of APP results in an aberrant increase in progenitor proliferation but impaired newborn neuron differentation, maturation and integration. Intriguingly, we found that APP is highly expressed in GABAergic interneurons and that specific deletion of APP in these neurons, but not in excitatory neurons, leads to similar neurogenesis defect. Our mechanistic and functional studies indicate that this activity is mediated by a general role of APP in regulating GABA release through its synaptic adhesion property.

\section{Conclusion}

$\mathrm{AD}$ is an age-related disease. Adult neurogenesis declines sharply with aging. Increasing evidence supports a role of hippocampal adult neurogenesis in brain function and its impairment in AD. Therefore, perturbation of APP-mediated adult neurogenesis may contribute to neuronal dysfunction and $\mathrm{AD}$ pathogenesis.

Huffington Center on Aging, Department of Molecular and Human Genetics, Baylor College of Medicine, Houston, Texas, USA
Published: 13 September 2013

doi:10.1186/1750-1326-8-S1-O4

Cite this article as: Zheng: Role of APP in neuronal function. Molecular

Neurodegeneration 2013 8(Suppl 1):O4.
Submit your next manuscript to BioMed Central and take full advantage of:

- Convenient online submission

- Thorough peer review

- No space constraints or color figure charges

- Immediate publication on acceptance

- Inclusion in PubMed, CAS, Scopus and Google Scholar

- Research which is freely available for redistribution
() Bïomed Central
C Biomed Central

(C) 2013 Zheng; licensee BioMed Central Ltd. This is an Open Access article distributed under the terms of the Creative Commons Attribution License (http://creativecommons.org/licenses/by/2.0), which permits unrestricted use, distribution, and reproduction in any medium, provided the original work is properly cited. 